\title{
Internal Audit in the Statutory Bodies and Government-linked Companies of Malaysia:
}

\section{The Never Ending Saga!}

\author{
Azham Md. Ali (Corresponding author) \\ Department of Accounting and Finance, Faculty of Management and Economics \\ Universiti Pendidikan Sultan Idris, 35900 Tanjung Malim Perak, Malaysia
}

Tel: $6054506500 \quad$ Fax: 6054594642 e-mail: azham @fpe.upsi.edu.my

\begin{abstract}
Ram Al Jaffri Saad, Ahmad Zamil Abd Khalid, Aryati Juliana Sulaiman
College of Business, Accounting Building, Universiti Utara Malaysia
\end{abstract}

\section{Juergen Dieter Gloeck}

Department of Auditing, University of Pretoria, Pretoria, 0002 South Africa

Received: September 01, 2011 Accepted: November 11, 2011 DOI: 10.5296/jpag.v1i2.1502

\begin{abstract}
This paper is part of the third and final study conducted on the state of internal audit in the public sector of Malaysia. The first study was concerned with the internal audit operations in the state and local governments found in Peninsular Malaysia (Azham et al 2007a), while the second study was concerned with internal audit in the nation's federal government ministries, departments and agencies (Azham et al 2007b). This third study covers 47 organizations at the federal government level, comprising 27 statutory bodies and 20 government-linked companies. From the face-to-face interviews conducted with internal auditors over the three year period 2005 to 2007, several notable audit features emerged as common to all 47 organizations. Some are depressing, while a few others are encouraging. All in all, however, the internal audit function in a majority of the organizations still leaves much to be desired. Also, it is notable that these findings are very much like those of the previous two internal audit studies (Azham et al 2007a; 2007b), and to make sense of the dismal state of the internal audit function in the public organizations, there is perhaps a need to look at the bigger context within which the internal audit function is found.
\end{abstract}

Keywords: Internal audit, federal government organizations, in-depth interviews, Malaysia 


\section{Introduction}

In Malaysia, a growing catalogue of organizational failures and mismanagement highlight both the need for, and current general lack of effectiveness of internal audit in both the public and private sectors. To date, there have been several research reports on the status of internal audit in general in Malaysia. However, until the recent studies by Azham et al (2007a) and Azham et al (2007b), there were none that specifically probed the situation that pertains in the nation's public sector.

This parade of organizational failures is despite it being the well documented legal and statutory responsibility of the management of public sector organizations to maintain an effective system of internal control, including the use of the internal audit function (e.g. Dowsett \& Morris 1981; Buttery 1985; Coombs \& Jenkins 1994; Jones \& Pendlebury 2000). And this has also arisen in spite of the publication, as early as 1979, of Treasury Circular No. 2: Implementation of Internal Auditing in Federal Government Agencies which detailed the requirement that the public sector entities in Malaysia have to have an internal audit function. This circular was replaced in October 2004 by Circular No. 9: Implementation of Internal Auditing in Federal Ministries and Departments and State Governments with a similar lack of positive impact.

This paper is one of the outcomes of a study and review of the internal audit situation in statutory bodies and government-linked companies in Malaysia. Like the previous two studies mentioned earlier, this study could lead to the clearer identification of problems and obstacles that have confronted, and continue to confront internal audit in Malaysia, and thereby focus efforts on achieving more realistic and substantial reform than the mere issuance of an official document such as the new (2004) internal audit circular. Further justification for such a study arises from the nation's need to find ways to be more competitive in all sectors of the economy, following the country's participation in the implementation of the ASEAN Free Trade Area (AFTA) agreements in early 2010. Internal audit that achieves its potential may actually be one of the most effective tools for all sectors to employ in their pursuit of such competitiveness.

\section{Literature Review}

In public sector organizations in general, the internal audit function holds high potential for promoting accountability and improving government performance. Thus, not surprisingly, several countries have developed policies aimed at strengthening public sector internal audit functions to enhance their capacity for contributing to these goals (Auditor-General of Australia 1990; Office of the Auditor General of Canada 1993 \& 1996; Light 1993; Newcomer 1994 \& 1998).

Policy measures include the following: requiring the establishment of internal audit units; establishment of standards for the professional conduct of audit work; training; resource allocation; expanding reporting arrangements, and broadening mandates to make auditors responsible for performance assessment. Also, the understanding that internal auditing is an important tool for accountability has led, in the case of the United States, to the traditional 
internal audit functions being transferred to Inspectors-General who report findings to both the Executive and to Congress. Thus, in the United States, internal audit is currently also a tool for external accountability - no more a mere tool of internal accountability intended to aid senior management of the government organizations.

Nonetheless, available evidence on the reality of internal audit operations in recent times shows that there is much room for improvement. In the United States, Canada and Australia, the common findings include: inadequate audit coverage, particularly of areas of major significance and high risk; a tendency to focus audits on compliance and regularity to the detriment of the performance of audits of economy, efficiency and effectiveness; and little attention being given to audit findings by senior managers within agencies. Furthermore, in Canada and Australia there exist deficiencies in the professional qualifications of audit staff and in the nature of senior management's involvement in audit planning. As for the United States, based upon his study of the work of the nation's Inspectors General, Light (1993:224) concludes that "government appears no more accountable today than before the IG Act."

As is perhaps to be expected, the lack of congruence between internal audit ideals and their realities does not just exist in public sector organizations in these three developed western countries. This is easily deduced from similar research conducted in recent years in the developing world: Sudan (Brierley et al 2001); Israel (Schwartz \& Sulitzeanu-Kenan 2002); and South Africa (Nair 2008). In fact, the situation may be considered definitively bad in Sudan.

As noted by Brierley et al (2001:73-4), in the developing country of Sudan, in North Africa, the typical internal audit department is largely engaged in the routine authorisation of transactions, is staffed by inexperienced and untrained personnel, and has insufficient credibility, independence or authority to act in the manner expected of internal audit personnel. Employing interview and observation research methods, Brierley et al concludes that in the few places where internal audit may be in operation, it has failed to meet even one of the five core standards described by the Institute of Internal Auditors (IIA 1979) in terms of independence, professional proficiency, scope of work, performance and management.

In Malaysia, until Azham et al (2007a) and Azham et al (2007b), very little was known of the state of internal audit in the public sector. As for internal audit in the private sector, the few studies conducted fail to provide an in-depth look at the processes and policies being applied. What was possibly the first internal audit study was conducted by the Malaysian Institute of Accountants (MIA) in June 1988 (MIA 1989). Following the publication of this report, the MIA in August 1989, conducted another questionnaire study (MIA 1991) which it says was more in-depth than the earlier one.

Besides these two studies conducted by the MIA in the late 1980s, there appears to have been just another two studies conducted in the next decade (Mathews et al 1995; Ernst \& Young et al 2000). While the MIA studies were concerned with an "overview" of internal audit, the next two focused on the nation's internal audit "profile". But just like the MIA studies, the latter two 
studies do not really provide much detailed information of the actual operation of internal audit in Malaysia.

In recent years, a team of researchers headed by the lead author of the present study embarked upon a number of studies on internal audit in Malaysia's public sectors. The first - Azham et al (2007a) - was concerned with internal audit in the state and local governments of Malaysia. From in-depth interviews conducted with internal auditors from 35 state and local governmental bodies (SLoGBs) located in Peninsular Malaysia in the third quarter of 2003, it was found that the internal audit function in these organizations faces numerous challenges. This is in addition to the fact that a mere 35 out of the then 202 SloGBs had an internal audit capacity. The problems range from inadequate staff numbers, and shortages of skills and training opportunities, to premeditated obstruction by auditees, amongst others, of the auditors in their attempts to perform their duties.

Following the completion of the internal audit study in SLoGBs, another one was embarked upon (Azham et al 2007b). This time it concerned internal audit in the federal government ministries, departments and statutory bodies. The findings from in-depth interviews conducted with internal auditors from a total of forty organizations revealed a number of serious shortcomings that far outweighed the few virtues identified. These shortcomings are that many internal audit units face staff shortages, and have staff lacking in internal audit competence. In addition, a majority of the internal audit units, most of which operate in outdated audit modes, have failed to get the right level of support and assistance from the Treasury and other statutory and interested parties. Worse, their effectiveness and efficiency are further threatened by the high-handed actions of the National Audit Department (NAD) which shifts its so-called cadre staff in and out of the internal audit units at will.

Since Azham et al (2007b) focused on a mere five statutory bodies (in addition to the ministries and departments) located at the federal government level, this third study which investigates the rest of the statutory bodies had to follow. Also, in order to provide a more complete picture of internal audit in the federal government, this latest study focuses on internal audit found not only in the statutory bodies but also in a selection of companies linked to the federal government. Providing descriptions of internal audit weaknesses and strengths found in the concerned organizations, this paper is one of two that discuss data from the third and final study on internal audit in the public sector of Malaysia.

The paper continues next with a section on research design. It is followed by a section on findings that address five key audit issues: age of internal audit; staff shortage; lack of competence in internal audit; use of outdated audit modes; audit independence (or its absence); and interaction between auditors and other parties in the organization. Following the section on findings is the final section on discussion and conclusions. 


\section{Research Design}

\subsection{Population and Survey Sample}

The government hierarchy has three levels: federal, state and local. Local governments include the city, town and local councils, depending on the territory's population. As mentioned earlier, two previous studies on internal audit, headed by the main author of the present study, covered the state and local governments located in Peninsular Malaysia (see Azham et al 2007a), and the federal government ministries, departments and agencies (see Azham et al 2007b). The present study covers 47 organizations at the federal government level: 27 statutory bodies and 20 government-linked companies. (See Appendix A for the list of the organizations.)

\subsection{Methods of Data Collection}

The main form of data collection was through face-to-face interviews with the internal auditors in the federal statutory bodies and government-linked companies. Appendix B provides the list of positions held by these auditors. As may be seen in Appendix B, out of almost fifty auditors interviewed, close to forty hold the post of head of the internal audit unit or department. (Note: For the rest of the paper the term audit unit will be used to refer to both audit unit and audit department.)

There are four parts to the questionnaire used during the interviews: (A) Background information; (B) Organizational Audit Practice; (C) Efforts in Support of Organizational Audit Practice; and (D) Internal Audit in the Organization and Government Sector as a whole. There are a total of 60 questions: 51 close-ended structured type (Parts B and C) and 9 open-ended semi-structured type (Part D). A total of twelve of the close-ended questions have more than one sub-part - (a), (b), etc. - to them. A majority of the close-ended questions also have spaces for participants to present their (unstructured) comments.

In regard to the categories of questions asked, the close-ended, structured type questions (Sections B and C) are concerned with the following: facts, such as the number of internal audit staff; perceptions, such as identifying knowledge elements needed by internal auditors to ensure the fulfillment of their present roles; and, the extent of interviewee's agreement with various statements. As for the open-ended, semi-structured type of questions (Section D), they may be divided into three categories: the history and future of the internal audit operation in the organization; weaknesses and strengths of the internal audit unit in the organization; obstacles to and potential for change in the operation of internal audit in the public sector as a whole.

The current paper is primarily concerned with answers to Sections B and C of the questionnaire provided by participating auditors. Azham et al (2011) focuses on answers provided to questions found in Section D. 


\section{Al Macrothink}

Journal of Public Administration and Governance

ISSN 2161-7104

2011, Vol. 1, No. 2

It is acknowledged that numerous resources were referred to in developing this questionnaire. For details, see Appendix A in Azham et al (2007a).

\section{Findings}

The face-to-face interviews conducted with internal auditors (the majority working in audit units, and a small minority working in audit departments) over the three year period of 2005 to 2007 , led to the discovery of several notable audit features. Some are disheartening, while others encouraging.

For the former, which include staff shortages, lack of competency and operating in less than advanced audit mode in a majority of the audit units, these are mere repetitions of the situation identified earlier for the nation's state and local governments (Azham et al 2007a) and federal government ministries, departments and agencies (Azham et al 2007b). As for the few encouraging features, like in the case of audit independence and that of audit / top management interaction taking place in a majority of the audit units - they signify that good things are still achievable in these organizations. All in all, however, there is still very much to be desired for internal audit in a majority of the organizations.

\subsection{Age of Internal Audit}

As shown in Table 1, more than half (25) of the organizations have had an internal audit function for more than a decade, while only approximately 15 percent, or seven of the organizations, have had an internal audit function for less than five years.

Table 1: Age of Internal Audit

\begin{tabular}{lcc}
\hline & Total & $\%$ \\
\hline Over 1 year old but less than 3 year old & 3 & 6.38 \\
Over 3 year old but less than 5 year old & 4 & 8.51 \\
Over 5 year old but less than 10 year old & 15 & 31.91 \\
Over 10 year old & 25 & 53.19 \\
\hline \multicolumn{1}{c}{ Total } & 47 & 100.00 \\
\hline
\end{tabular}

Hence, it may be concluded that for more than half of the organizations the experience with internal audit has been a rather long one. For at least three of these organizations whose audit units have been around for some time, the experience has been a good one.

Case A:

The audit unit was formed in the early 1990s as part of the corporatisation of a statutory body. The auditor concerned mentioned that in the beginning there were very few audit staff around and they had focused on financial and compliance audits. In recent years, as described by the auditor, the following has taken place: 
Nowadays, the audit scope does not just focus on financial audit but is also concerned with the performance of the organization's subsidiaries. When it concerns the structural side, it has expanded. Currently, the audit department has a general manager with three managers in comparison to just one manager at the time of its setting up. And, the total number of staff today is 15 including the clerical staff. The audit department is also concerned with management audit. Since 2001, the department has had both IT and engineering units. This means that the staff in the department are equipped with a variety of different and appropriate qualifications.

\section{Case B:}

The audit unit was established in the late 1980s. The following came from the auditor concerned over what has taken place over the years:

It may be admitted that the department has gone through many changes. Previously a lot of parties would usually point fingers and fail to appreciate the efforts made by the unit. The support coming from top management was also inadequate. But, in recent time, the perception has changed. They have more or less understood our role which is not to search for the mistakes of others but more towards giving advice to friends.

\section{Case C:}

Compared to the other two, this audit unit has been around for the longest time. To be more exact, it was formed in the late 1970s. As stated by the auditor concerned:

These days there is the change from compliance to performance audit. Internal audit is able to give added value to the organization. Nonetheless, the compliance audit is not forgotten completely - there is the spot check approach taking place to ensure that the compliance is as it should be. The internal audit has changed with the implementation of the strategy to provide knowledge and to change perception of the auditee on its importance. With auditee gaining the understanding, it is easy to conduct an audit. This may be seen from the audit visit chart which has come down since 2005. All in all, the internal audit is successful in changing the perception. It is now acting as a consultant or a partner to the rest of the organization and is successful in changing the organization as a whole.

While there is a small group of organizations such as those three above where over time encouraging developments have been taking place in their audit units, the truth of the matter is that there exists another group of organizations where hardly anything interesting has ever taken place. The next three cases will illustrate the point.

Case D: 
As mentioned by the internal auditor, this statutory body has had an internal audit function since the early 1980s - but hardly any sort of changes have taken place since that time. So, for example, the number of staff has remained the same: two. The kind of audit taking place is also the same: compliance. This is in spite of the unit being faced with an increasing amount of work in recent years!

What makes the situation so depressing is that since its creation, the post of internal auditor has never seen any upgrading, the auditors continue to get the same (low) salary amount year in year out. Given this situation, they are not finding it easy to audit those whose salary grades are now much higher than theirs. Furthermore, their stagnant salary grades have led to their feeling demoralized in their jobs. This means that for many years now they have not been able to give their very best to the organization. Apparently hardly anyone in the organization is bothered that such is the situation with the internal auditors, so it should perhaps not be surprising to find that one of the two auditors who was interviewed for the study turned the interview into a session where he or she poured out all the unhappiness inside him or her! Pity the interviewers.

\section{Case E:}

Just like the previous case, the audit unit, which has been around for almost a quarter of a century, has seen little change taking place over the years. The number of audit staff is unchanged at three. The kind of audit delivered has also been the same. While the main problem of the audit unit is an "unsuitable" audit manual, its weakness is its staff who are lacking in up-to-date knowledge needed to improve their audit performance.

Perhaps the latter is not that surprising since the auditor stated early in the close-ended section of the interview that there was no training and development program in place for the staff to gain up-to-date knowledge on audit techniques, policies, procedures, etc. Later, in the open-ended section, the auditor admitted that this was the fundamental contributor to the main problem and leading to the weakness experienced by the audit staff. As he or she puts it:

The fundamental factors leading to problems and weaknesses are that the courses and training offered to the unit are inadequate.

Despite all this, he or she claims that the statutory body is satisfied with the audit performance. That the organization has failed to get the most from the audit unit's potential is confirmed by his or her own admission that, in his or her view, the performance of the unit is merely average.

\section{Case F:}

Though this unit has been around since the first half of 1990s, the audit scope has not changed. The original staff complement of three has now increased to a meagre four. However, this is just one of numerous problems faced by the audit unit. Other problems besetting the audit unit, such as the lack of training, inadequate computer facilities and under-trained staff, are most probably 
due to the fact that those in top positions in the organization have never really wanted much from the audit unit. In the interview the auditor claims that these people are comprised of long serving "PTD officers". They are more powerful than whoever has officially headed the organization over the years since the organization heads usually only stay in the post for a maximum of two years before he or she is moved out and replaced by someone else.

That this audit unit is one of the saddest of all the audit units covered in the study is signified by some other details provided by the auditor in the open-ended section of the interview. For example, in regard to the fundamental factor leading to the various problems and weaknesses faced by the audit unit, he or she says the following:

The organization may probably feel that the internal audit unit is not important.

Next, in regard to whether the organization is satisfied with the audit performance, without mincing his or her words, he or she says:

They are satisfied since the internal audit has failed to function well!

At the end, when talking about the hopes and aspirations of the organization for its audit unit, and again when discussing whether the unit is likely to achieve greater significance in the future, not surprisingly he or she had the following things to say:

Regarding the hopes and aspirations of the organization for its audit unit: Most probably to merely remain as it is presently.

Regarding future improvements: I do not know. ... It is because there are too many problems around as I mentioned earlier. There is also the additional fact that the audit unit is merely existing and nothing more.

The reality of this and other things he or she describes are hard to deny, and is backed by the initial experience of the interviewers, themselves. For example, they observed that the office of the audit unit was rather small and that the place was a bit messy. This led them to feel that the organization did not care much for the audit function. This first impression was supported by the auditor grumbling about the one computer which had been out of order for some time. Apparently, management failed to see the need for the computer to be repaired right away! It is also notable that during the interview the auditor, who appeared to want to tell all, was at times fearful of sharing the problems he or she is facing in the organization. This explains his or her reluctance to have the open-ended section of the interview tape recorded. It also explains why he or she made the request to have the tape recorder turned off when he or she wanted to share more sensational issues and experiences!

Having said all that, it is perhaps worth noting that although the situation faced by the audit unit appears to be quite unbearable, in the close-ended section of the interview, in response to the 
questions on support coming from top management for the internal auditors, the very same auditor responded "Agree" to two statements and the less unfavorable "Uncertain" to the third one. Of the statements the auditor agreed with, one is concerned the implementation of audit suggestions by the top management, while the other concerned top management's giving sufficient feedback to the audit unit upon getting the audit findings and suggestions. The "Uncertain" response concerned the statement about top management recognizing the achievement of the audit unit. Also, it is notable that in response to the question of whether there are regular meetings between auditor and top management, the answer given was the favorable "Yes", plus the detail that there is a minimum of four meetings per year. These positive answers are far from consistent with this auditor's responses to the initial questions, and his or her opinions expressed in response to the open ended questions: could this be the very same person?

As it turns out, this auditor was not the only one providing inconsistent answers. There are several other auditors interviewed whose responses were found during the data analysis stage to be fraught with inconsistencies. That is, what they say in the close-ended section is different to their responses in the open-ended section or vice versa.

In an ideal situation, these auditors should have been asked to clarify their inconsistent responses soon after their interviews were completed. But due to the fact that the data collection alone took over three years to complete and the data analysis could only begin some months after the completion of the very last interview session, it was decided that to go back to the interviewees for clarification may not be the practical thing to do. This is primarily due to the fact that many would probably have struggled to recall their earlier responses while some others might have already retired or left their posts.

There is also one other justification for not contacting the interview participants to have them explain their inconsistencies. As stated clearly by Kvale (1996:14), who is referring to interview data in particular:

The aim of the qualitative research interview is not to end up with unequivocal and quantifiable meanings on the themes in focus. What matters is rather to describe precisely the possibly ambiguous and contradictory meanings expressed by the interviewee. The contradictions of interviewees may not merely be due to faulty communication in the interview situation, nor to their personality structures, but may in fact be adequate reflections of objective contradictions in the world in which they live.

All in all, aside from Cases C, D and E which depict the less-than-healthy audit practice among those audit units which have been around for some time, there are other bewildering cases too. These other cases are concerned with audit units which have failed to function actively from the time they were first set up, or that have only functioned intermittently from the moment they were first set up. 


\section{Macrothink}

A case in point concerns an audit unit whose auditor claimed in the close-ended section of the interview that the unit had been set up in 1998. Later, in the open-ended section, he or she mentions that the unit had closed shop for about a year due to the absence of an audit head, and had only re-opened about a year and a half ago. Today, the audit unit has only a single staff member. This, and a few other issues it is facing, as mentioned by the auditor in the interview, provide the picture that the unit might as well have remained closed down! That said, there does appear to be a number of encouraging aspects of this audit operation in areas such as independence and training and development programs.

\subsection{Staff Shortage}

More than a third or 17 of the units have got at most a meagre complement of five staff members. Also, just less than two fifths or 18 units possess more than eleven staff members. See Table 2.

Table 2: Audit Personnel Available

\begin{tabular}{lcc}
\hline & Total & $\%$ \\
\hline Fewer than 3 & 4 & 8.51 \\
Between 3 and 5 & 13 & 27.66 \\
Between 6 and 10 & 12 & 25.53 \\
Over 11 people & 18 & 38.30 \\
\hline Total & 47 & 100.00 \\
\hline
\end{tabular}

Hence, not surprisingly, a majority of the auditors are not happy with the number of audit staff found in their audit units. To be more exact, auditors from well over two-third (or 33) of the audit units claim that they have an insufficient number of staff members for their work load. As can be seen in Table 3, over three fifths or 20 out of 32 audit units with staff shortages, are more than eleven staff members short! If we include those units where the shortage is at least six staff members, the figure reaches over four fifths, or 26 of all audit units that are experiencing a staff shortage.

Table 3: Audit Personnel Shortage

\begin{tabular}{lcc}
\hline & Total & $\%$ \\
\hline Inadequate by 3 or less & 2 & 6.25 \\
Inadequate by 4 to 5 & 4 & 12.50 \\
Inadequate by 6 to 10 & 6 & 18.75 \\
Inadequate by over 11 staff & 20 & 62.50 \\
\hline Total & $32 *$ & 100.00 \\
\hline
\end{tabular}

* It is 32 and not 33 since one of the auditors has failed to state the exact number needed. 
Not surprisingly, several auditors dwelt on the issue of staff shortage in the open-ended section of the interview. Invariably, these auditors refer to the fact that one of the main weaknesses in the audit performance is concerned with the extreme shortage of audit staff, especially in the face of a burgeoning audit responsibility and an expanding audit scope. Several of them also made it clear that this staffing problem is caused by the limited number of audit post warrants issued by the Public Service Department (PSD). There were two auditors who tried to explain the origin of the problem for the public sector as a whole. Their views are worth noting in more detail, and are provided next.

The first auditor:

He or she is attached to an audit unit which was formed in recent years. In the close-ended section of the interview, he or she claimed that there is no auditor shortage. But early on in the open-ended section, he or she pointed out that one of the two main problems faced by the unit is staff shortage. (The other one is that staff lack appropriate experience as auditors.) As he or she puts it, this has led the unit to function "rather slow". Later, he or she also expressed the view that the audit staff shortage is one of the two factors limiting the role played by auditors in the public sector as a whole these days. (The other one is concerned with the salary grade of auditors.) He or she believes that this is due among others to the traditional dislike that civil servants have for their auditors. He or she claims that that is not the case in the private sector.

The second auditor:

He or she is an auditor from a thriving audit unit, who touches on the problem of staff shortage in more than one place in the interview. In the close-ended section, he or she made it clear that the number of staff in the audit unit needs to be expanded to more than three times the present number. Later, in the open-ended section, staff shortage is mentioned as one of the two main problems faced by the audit unit. (The other main problem is that staff are lacking in competency - in particular in IT audit.) It is notable that at the end of the interview, while talking about the less-than-healthy state of the public sector audit function as a whole, he or she came out with some very interesting remarks to explain the origin of the problem of the audit staff shortage. As he or she puts it:

Internal audit has not yet reached the level which may be expected of it. It is working, but it is not aggressive. This is probably because the top management is not that supportive. As an example, they have failed to add staff to the audit unit.

Next, he or she has mentioned the following:

There is weak set of checks and balances. Audit is considered lacking in importance. It is needed in the organizational chart, but it is not given the attention it is due. 
It appears that there is more than one reason behind the phenomenon. The following is what he or she says to be the fundamental factors behind internal audit's challenges:

Personal interest or the interest of one's own department. There is a conflict of interest. There is also the lack of understanding and awareness over the audit definition itself.

It is uncertain to what extent these views are anything more than mere conjecture. For the record, he or she has been around as an internal auditor in the organization for just a few years. Prior to this, he or she was working in the private sector. All in all, he or she has been in the field for almost fifteen years. At any rate, what is so refreshing about this view is that so many auditors from other organizations have failed to note the occurrence of the same situations in their organizations. In almost all of these other cases, the auditors say that the heads of the organizations are in full support of the audit function. And yet in many cases it is found that the support does not go to the extent of adding staff to their audit units! Hence, the claim made by the auditors concerned on their bosses is mind boggling to say the least.

A case in point involves an audit unit which has been around for ten years but whose staff complement is only two. In the open-ended section of the interview, the auditor mentions that one of the main problems faced by the audit unit is that it lacks the staff numbers to audit the headquarters and the various branches throughout the country. It seems the help is not forthcoming from the top of the organization to have the number of audit staff increased. As the auditor mentioned while talking about the strength of the audit unit during the open-ended section of the interview:

We get the strong support from the CEO whereby he would usually be defending the auditor in the dispute with auditee.

All in all, it may be surmised that there is actually no real support for the auditors such as this one, coming from top management, if at the end of the day they continue to function miserably due to the very limited numbers of staff in the audit units. The so-called support from the top is a sham! Perhaps it is time for the auditors concerned to acknowledge this ugly fact. It looks downright pathetic to blabber about their staff shortage when in the next breath the auditor is talking excitedly about the strong support for the internal audit coming from the top of the organization.

\subsection{Lacking in Competency in Internal Audit}

It is in the open-ended section of the interview that many auditors talk about staff lacking in audit competency as the primary problem or weakness. Perhaps this is not surprising for auditors coming from at least seven audit units: none of these units have training and development programs for the audit staff. It appears that there are various reasons leading to this situation, as reflected in the following two cases. 


\section{$\Lambda$ Macrothink}

Case A:

It is perhaps to be expected that there is no training and development program whatsoever for the internal auditors even though they are thirsty for such: the top management and the auditors are not on good terms. It seems that the top management of the organization is antagonistic towards the auditors. So, it is inevitable that little support and funding should be made available for the auditors to be well equipped to conduct audits. As a result, as revealed early on in the open-ended section of the interview, very few changes have taken place in this two decade-old audit operation.

\section{Case B:}

This unit has been around since the early 1980s. Though the number of auditors has increased over the years, it is still experiencing a staff shortage and the problem of staff lacking in competency. Related to the latter issue, in the open-ended section of the interview its auditor says that for the unit to increase its performance, the staff have got to attain an appropriate level of expertise - through training and development programs. But here lies the problem: the organization just does not have the budget for such training, even though the staff are quite interested. Perhaps it is not entirely the fault of the organization. As the auditor mentioned:

The courses or training are usually quite expensive. Also, they mostly take place in Kuala Lumpur. This requires a lot of money.

Aside from the issue that auditors from several audit units fail to enroll in the staff training and development programs that are on offer, there is the issue that for those who do get the chance of participating, their opinions vary as to the sufficiency, completeness and current relevance of the courses. See Table 4.

Table 4: Opinion on Staff Training and Development Programs

\begin{tabular}{lcccccc}
\hline & \multicolumn{2}{c}{ Sufficient } & \multicolumn{2}{c}{ Complete } & \multicolumn{2}{c}{ Current } \\
\cline { 2 - 7 } & Total & $\%$ & Total & $\%$ & Total & $\%$ \\
\hline Yes & 28 & 59.57 & 25 & 53.19 & 29 & 61.70 \\
No & 8 & 17.02 & 6 & 12.77 & 1 & 2.13 \\
No Comment & 0 & 0.00 & 4 & 8.51 & 4 & 8.51 \\
No Answer & 11 & 23.40 & 12 & 25.53 & 13 & 27.66 \\
\hline Total & 47 & 100.00 & 47 & 100.00 & 47 & 100.00 \\
\hline
\end{tabular}

That there is a big question mark over the quality of staff training and development programs is underscored by the views heard in the open-ended section of some interviews. To be more exact, there are auditors who claim in the close-ended section of the interview that the training and development programs for the audit staff are sufficient, complete and up-to-date. But, what they say later in the open-ended section is the opposite. See the next three cases. 
Case C:

This audit unit is quite an active one with more than a few auditors around. The unit is also one of those which has all the training programs needed provided internally. Perhaps there is nothing wrong with such an arrangement. But what is a little disconcerting is the presence of much confusion as to the quantity and quality of these programs, since the answers elicited from the two sections of the interview are not consistent with each other. While the close-ended section has answers that lead to the picture that the training programs are sufficient, complete and up-to-date, over several parts of the open-ended section, the auditor talks about the lack of training experienced by the audit staff. For example, in answering the question of the main problem faced by the audit staff, he or she mentions their lack of knowledge in audit which is caused by their lack of training. In a later part of the interview, he or she again emphasized the need for the auditors to undergo more training.

\section{Case D:}

The unit has been around for over three decades! All in all, from the close-ended section of the interview, there is hardly any issue or problem faced by the unit, other than a staff shortage. However, in the open-ended section, a totally different story of the audit function is laid bare. In regard to the training and development programs in particular, even though in the close-ended section it is mentioned that these are sufficient, complete and up-to-date, in the open-ended section of the interview, the auditor talks about inadequate training as one of the weaknesses experienced by the audit unit. He or she also mentioned that the staff has no opportunity whatsoever to learn modern audit techniques. Finally, he or she refers to the need for a bigger budget for the unit and more training opportunities to be made available to the auditors.

\section{Case E:}

The unit has been around for a quarter of a century already. Over time, a number of positive developments have taken place. However some issues and problems were uncovered in the open-ended section of the interview which appear to have been hidden by the kind of answers provided in the close-ended section. For example, the auditor claims in the close-ended section that the training and development programs are sufficient, complete and up-to-date. But, in the open-ended section, he or she mentions the weakness experienced by the audit unit in the form of having limited knowledge in certain areas. Next, in talking about the origin of this problem, the auditor refers to staff who are lacking in training and exposure in these fields.

Finally, there is also the issue of audit units finding it hard to ensure the competency of their audit staff. Their struggle is due to both internal and external factors. As described next in Case $\mathrm{F}$, the former comes in the form of an organization head who is practicing favoritism in allocating funds for training. As for the latter, as described in Cases $\mathrm{G}$ and $\mathrm{H}$, it is concerned with the inadequacies of the trainers themselves! 
Case F:

The auditor mentions that the main problem faced by the audit unit is that its staff lack audit experience and come into the unit without proper qualifications in areas such as accounting. As a result, these audit staff have to undergo training delivered by the deputy manager of the audit unit on every Friday afternoon and on every Saturday. Apparently they have no other choice of method for improving the staff competency since every single application forwarded by the audit staff to undergo training outside the unit has always been rejected by the authorising parties outside the audit unit. That does not seem to be the case when non-auditors apply for job training outside the organization. In fact, as the auditor noted, in these cases, it is none other than the head of the organization him/herself who provides the full support for these non-auditors to go for training outside.

All this has led the concerned auditor to claim that favoritism ("pilih kasih") is rampant in the organization. He or she has further pointed out that such favoritism needs to be discarded and an appropriate and fair amount of funds allocated to the audit unit for job training - if the performance of the audit staff is to be raised. Meanwhile, it is interesting to find that this very auditor has earlier noted in the close-ended section of the interview that the (100 percent internally provided) training and development programs undergone by the audit staff are in fact sufficient, complete and up-to-date.

\section{Case G:}

The audit unit is facing numerous problems including the fact that its very small staff complement lacks competency and experience in audit. In the close-ended section of the interview, the auditor concerned in fact mentioned that the training and development programs are inadequate and incomplete. Also, he or she provides "No Comment" as the answer to their current relevancy. Later, in the open-ended section of the interview, it is revealed that the training and development programs delivered by parties such as INTAN, NAD and the Office of the Accountant General have failed to provide much assistance.

\section{Case H:}

The audit unit has been around for over twenty five years. It appears to be operating quite well. This may be seen by the fact that the auditor him/herself rates the audit performance to be excellent. But there are problems concerning the staff: there is not enough of them and the few that there are lack the right skills. It seems the training and development programs have nonetheless been sufficient and are of current relevance. Sadly, the auditor is unable to say whether or not these are complete. His or her answer is simply "No Comment". Later, in the open-ended section of the interview, the auditor talks about the lack of exposure to new audit techniques. He or she blames it on the failure of the various organizations (other than the Institute of Internal Auditors Malaysia) which have failed to look into this matter. 


\section{Macrothink

\subsection{Less than Advanced Audit Mode}

The original definition of internal auditing provided by the United States based IIA in its Standards for the Professional Practice of Internal Auditing (SPPIA) states (IIA 1979):

Internal auditing is an independent appraisal function established within an organization to examine and evaluate its activities as a service to the organization. The objective of internal auditing is to assist members of the organization in the effective discharge of their responsibilities. To this end, internal auditing furnishes them with analyses, appraisals, recommendations, counsel and information concerning the activities reviewed.

In its more recent definition the body provides a broader goal for internal auditing (IIA 2003):

Internal auditing is an independent, objective, assurance and consulting activity designed to add value and improve an organization's operations. It helps an organization accomplish its objectives by bringing a systematic, disciplined approach to evaluate and improve effectiveness of risk management, control and governance processes. (Emphasis added.)

It seems however that this new definition of internal auditing has little relevance in the day-to-day operation of the auditors in the Malaysian federal organizations. On reviewing current knowledge elements professed by those interviewed, the responsibilities or tasks specified in the organizations' audit charters, and finally on specific activities undertaken when auditing, these are among the areas that showed that auditors from a significant proportion of the organizations do not have much awareness of the importance of risk as part of the new approach to conducting an audit.

Specifically, on the matter of knowledge elements which an internal auditor needs in order to perform his or her "current" role in the organization, a majority of those interviewed provided answers that demonstrated either a "traditional" or a "modern" mode of internal auditing, as opposed to that of the more appropriate "advanced" type (see Ridley \& Chambers 1998). Table 5 shows that areas such as auditing, financial accounting and control are the favoured areas of focus and competence, in contrast to risk vocabulary, concepts and management techniques, globalization and forensic auditing. 
Table 5: Current Knowledge Elements

\begin{tabular}{lcc}
\hline & Total & $\%$ \\
\hline Financial accounting & 43 & 91.49 \\
Red flags (indicators of fraud such as unauthorised transactions, & 42 & 89.36 \\
overrides of controls, unexplained pricing exceptions or unusually & & \\
large losses) & & \\
Types of control (preventive, detective, directive and corrective) & 42 & 89.36 \\
Auditing and analytical skills & 41 & 87.23 \\
Interrogation techniques & 40 & 85.11 \\
Communication techniques & 40 & 85.11 \\
Types of frauds & 37 & 78.72 \\
Ethics & 36 & 76.60 \\
Computer technology & 35 & 74.47 \\
Cost accounting & 30 & 63.83 \\
Risk vocabulary, concepts and management techniques & 28 & 59.57 \\
Legal & 27 & 57.45 \\
TQM & 26 & 55.32 \\
ISO framework & 21 & 44.68 \\
Globalization & 17 & 36.17 \\
Forensic auditing & 13 & 27.66 \\
Others - Construction Technology, Hotel Management, Building & 1 & 2.13 \\
Management and Maintenance & & \\
\hline
\end{tabular}

Another sign that audit practice is taking place in a less than "advanced" mode in many federal organizations was revealed when the auditors were questioned about their audit charters. The presence of an audit charter may be considered of utmost importance for internal auditors and for those with whom they interact. This is because this document should, at the very least, be able to clarify many matters that come under the purview of the internal auditors. All but three organizations have developed such a document for their auditors.

The specific areas of responsibility or tasks disclosed in audit charters, are presented in Table 6. It is in the detail that it becomes obvious that at best the majority are operating in "current" mode, and not "advanced". The most popular areas include appraising the adequacy and effectiveness of internal controls and assessing compliance with policies, plans, procedures and law. As for the less popular (more "advanced") tasks, these include fraud investigation, assessment of risks faced by the organization and IT audit. 
Table 6: Responsibilities or Tasks Specified in Audit Charter

\begin{tabular}{|c|c|c|}
\hline & Total & $\%$ \\
\hline $\begin{array}{l}\text { Appraise the adequacy and effectiveness of internal controls - covering } \\
\text { both accounting and administration - that are applied in all the activities of } \\
\text { the organization }\end{array}$ & 43 & 97.73 \\
\hline Assess the extent of compliance with policies, plans, procedures and law & 43 & 97.73 \\
\hline Verify the existence of assets and proper safeguards for their protection & 41 & 93.18 \\
\hline Appraise the economy and efficiency with which resources are employed & 37 & 84.09 \\
\hline Ascertain the accomplishments of established objectives and goals & 35 & 79.55 \\
\hline Review information reliability and integrity & 34 & 77.27 \\
\hline $\begin{array}{l}\text { Contribute towards the organization's governance process by evaluation } \\
\text { of and recommendation of improvement to the manner in which the } \\
\text { organizational values and goals are established, communicated and } \\
\text { preserved and accountability ensured }\end{array}$ & 32 & 72.73 \\
\hline Investigate frauds & 30 & 68.18 \\
\hline Provide advice in setting up policies and procedures & 29 & 65.91 \\
\hline Suggest steps in improving the working of the governmental body & 29 & 65.91 \\
\hline $\begin{array}{l}\text { Identify and assess "risks" faced by the organization and analyse and } \\
\text { evaluates controls established to respond to such risks }\end{array}$ & 28 & 63.64 \\
\hline $\begin{array}{l}\text { Hand in objective and timely reports to the department head so that he or she } \\
\text { is informed of the relevant aspects of the organizational position and } \\
\text { performance }\end{array}$ & 27 & 61.36 \\
\hline $\begin{array}{l}\text { Conduct financial auditing activities in close cooperation with the external } \\
\text { auditors }\end{array}$ & 24 & 54.55 \\
\hline $\begin{array}{l}\text { Conduct financial auditing activities separate from those conducted by the } \\
\text { external auditors }\end{array}$ & 25 & 56.82 \\
\hline Ascertain the proper dispensing of government revenues & 21 & 47.73 \\
\hline Conduct information technology audits (IT Audit) & 19 & 43.18 \\
\hline Conduct special projects & 17 & 38.64 \\
\hline $\begin{array}{l}\text { Assess the presence of adequate criteria to be used by the governmental } \\
\text { entity in determining whether its objectives have been accomplished }\end{array}$ & 11 & 25.00 \\
\hline Conduct detailed checks on expenditures prior to payment & 9 & 20.45 \\
\hline Provide information to the relevant outside party & 6 & 13.64 \\
\hline Some other responsibilities & 5 & 11.36 \\
\hline
\end{tabular}

Regarding IT audit in particular, many auditors mentioned in the open-ended part of the interviews that they have failed to implement it due to the lack of specific knowledge.

There is an auditor who claims that in recent years the audit unit has entered a new era compared to the miserable time it experienced before. For one thing, the audit staff today have what it takes to be auditors through an intensive training program provided internally. This takes place in an organizational environment that is rather hostile to the internal auditors. Nonetheless, the auditor concerned is not so proud as to hide the fact that the audit unit is still facing one real weakness: none of its personnel is an expert in ICT. As he or she puts it:

There is a weakness in the form of internal audit unit having no expertise in IT. None of the auditors here possesses expertise in IT. Looking at the expanding use of computers these 
days, there is much need for the internal audit unit to have staff who possess expertise in that area.

It is noticeable that the problem concerning IT audit has led auditors from a number of audit units to say that the future may see the outsourcing of such audit in their organizations. But there is one particular case where the organization chooses to do things differently - by looking out for the right candidate to come into the audit unit.

To be more exact, the auditor mentions at some length that the unit has got no expert in IT audit. In the open-ended section of the interview, it is revealed that that is the main problem faced by the audit unit and that it has led to the failure of the unit to audit the computer system in the organization. The auditor has also said that the post is still vacant since the newspaper ads on the vacancy have so far failed to bring in the right candidate. In other words, those coming for interview possess nothing more than the usual external audit job experience. Since the organization is in dire need of a person with IT audit expertise to audit its computer system, the organization is left with no choice: it must continue looking for him or her.

Finally, still another sign of the ongoing use of outmoded audit practice became apparent when the auditors answered questions on the specific tasks done while conducting the audit. Those which should perhaps be most prominent, such as maintaining awareness over the potential for fraud during the audit planning stage, and the use of risk assessment techniques, are performed by auditors from just over half to fewer than three quarter of the organizations contacted. See Table 7.

Table 7: Specific Activities Undertaken When Auditing

\begin{tabular}{lcc}
\hline & Total & $\%$ \\
\hline $\begin{array}{lc}\text { Prepare annual audit plan detailing the auditable areas, the resources required } \\
\text { and the duration of each audit activity during a calendar year }\end{array}$ & 47 & 100.00 \\
Prepare audit report & 44 & 93.62 \\
Conduct interviews & 43 & 91.49 \\
Develop working papers & 42 & 89.36 \\
Review prior audit reports and other relevant documentations & 41 & 87.23 \\
Perform follow-up audits on all audit findings sometime after the issuance of & 40 & 85.11 \\
the audit report & 38 & 80.85 \\
Develop recommendations when appropriate & 37 & 78.72 \\
Monitoring the progress of audit work & 36 & 76.60 \\
Discuss recommendations with auditee & 36 & 76.60 \\
Evaluate the relevance, sufficiency and competency of evidence & 36 & 76.60 \\
Use audit aids such as flowcharting, internal control questionnaires and & & \\
checklists & 36 & 76.60 \\
Require written response from auditee (to include among others plans for & & \\
corrective action and the date by which action will be implemented) & 35 & 74.47 \\
Disseminate audit outcome to the appropriate individuals & 34 & 72.34 \\
Use computer & 34 & 72.34 \\
Use risk assessment technique to inform the audit planning and resource \\
allocation process & &
\end{tabular}


Review audit work papers by senior auditors 2011, Vol. 1, No. 2

\begin{tabular}{lcc} 
Maintain an awareness of the potential for fraud while auditing & 32 & 68.09 \\
Perform Analytical Review Procedures & 32 & 68.09 \\
Execute judgmental sampling & 30 & 63.83 \\
Execute statistical sampling & 30 & 63.83 \\
Consider the potential for fraud during planning stage & 24 & 51.06 \\
Some other operational details are executed & 4 & 8.51 \\
\hline
\end{tabular}

\subsection{Audit Independence}

For both external and internal auditors, their independence from those they audit is crucial for the success of their function. It is perhaps more difficult however for the latter compared to the former to achieve independence because they are actually employees of the organization. The next three cases should depict this very fact rather well.

\section{Case A:}

In this audit unit, the audit personnel have to work in quite a horrendous environment. This is deduced from the various answers given in both close and open-ended sections of the interview. In relation to the subject of independence in particular, the auditor talks about his or her audit report failing to be integrated with management's action plan that is supposed to show the action management will take for each recommendation made by the auditor. Further, the auditor mentions that neither the audit unit nor any other party is required by the organization to monitor the performance of auditee in relation to the recommendations made by the auditor in the audit report. Worse, following the issuance of the audit report there are only a limited number of situations where the auditee is required to provide some sort of feedback to the relevant parties in the organization as to what its intended corrective actions are.

As if all this is not bad enough, the audit staff have had to face tough times outside of office hours from those whose errant conduct has been exposed. Without specifying what these are, the auditor has simply said that these parties commit actions which are infuriating to the auditors.

There is perhaps no surprise why the independence of the audit unit is still such a long way from being achieved. As disclosed by the auditor, the audit committee which, even though it is around, is not that active! Indeed, when a body such as an audit committee, whose function among others is to work closely with the auditors, is around merely to look good on paper, what does one expect to take place on the ground? Miracles?

\section{Case B:}

The audit personnel appear to have it worse than their counterparts in the previous case. In the first place, in the eyes of many in the organization, the audit unit has been turned into a dumping ground of sorts: the present audit head was moved to the position even tough he or she has no knowledge whatsoever about internal auditing. Apparently he or she was moved to the audit unit 
as a result of the problems he or she was having with top management. But there are other disturbing details.

(Note that this is not the only case of an internal audit unit being made into a dumping ground! At least one other audit head got there because a new head of the organization was appointed. The audit head, who was previously number two in the organization needed to be shifted out because of the appointment of the new head. The internal audit unit was his/her destination! As if this is not bad enough already, he or she needs four to five years to know what exactly he or she needs to do as auditor. During the first year as audit head, as he or she describes it, he or she was totally blank!)

In regard to the subject of independence, in the close-ended section of the interview, the auditor has given "No" as the answer to the statement regarding freedom to produce the audit report when its contents are not to the liking of certain parties in the organization. The auditor is also unable to say the desired "Yes" to the following two statements: no obstruction whatsoever in auditing any departments, records, assets and employees of the organization; and possess frequent access with senior officers. To be exact, for both cases, the answer given is "Other". It is notable however that in the case of the former statement, the following explanation is also attached:

Free to conduct audit but there is little cooperation.

Elsewhere in the interview, it has also been revealed that once during the two decade history of the audit operation, an audit head was demoted due to his or her "aggressive" reporting. And just like in the case of the previous audit unit, the auditor reveals that their audit reports are devoid of the so called management's action plan comprising information on the kind of action to be taken and the time period within which such action should take place for each and every single audit suggestion made by the auditor. Worse, following the issuance of an audit report, the need for feedback from the auditee to the relevant parties in the organization occurs irregularly, if at all. As if all this is not terrible enough already, neither the audit unit nor any other party in the organization is required by the organization to monitor the auditee as to whether or not it has acted on the recommendations made by the auditor in the audit report.

Case C:

This is probably the saddest audit unit among those covered in the current study. The audit unit is facing quite a frightful working environment due to its strained relationship with the top management. This is acutely reflected by the fact that the audit head and his or her single staff member asked for the interview to take place outside the organization. The reason given is this:

We are fearful that others would be listening to our conversation while the interview is taking place. 
During interview, it was mentioned that there are no regular meeting between audit head and top management. The auditors also dwelt much on the subject of audit reports, which they are supposed to issue after completing the audit assignments.

First, they claim that their audit reports exclude the so-called management action plan. Hence, there is no knowing what an auditee's responses are and the time frame of these responses. The absence of management action plan in the audit reports would still perhaps be acceptable if the concerned auditee were required by the organization to provide some kind of feedback to the relevant parties in the organization. The truth is that such action on the part of an auditee is required on certain occasions only. Furthermore, the organization has not made it a requirement for the auditor, nor for any other competent party, to monitor whether the concerned auditee has taken the audit report's suggested actions.

Second, over an item in the close-ended section of the interview which concerns the daily activities of an audit unit relating to the issuance of the audit report, the auditors provide the answer "No" to the following statement: free to produce the audit report even though the contents may not be to the liking of certain individuals or groups in the organization. Painful elaboration of this situation was provided in more than one place later in the open-ended section of the interview. For example, the reply to the question "to what extent has the internal audit in the organization changed over the years?" was:

There have never been any changes since it was first set up especially when it concerns audit implementation. ... There has also been a case where the audit report issued has led to us being confronted with one question after another: we have without a doubt been attacked savagely by the concerned parties!

Next, the auditor says that this kind of thing does upset him or her so very much. Working within such a dire environment, the auditor's cynical reply to the question on whether the organization is satisfied with the performance of the audit unit is not unexpected:

In regard to audit, these days they are certainly quite satisfied since we in the audit unit have stopped issuing the audit report! The audit unit has been asked to attend to activities other than audit, such as working on rules and legislations, investigating poison pen letters, etc. We are not encouraged to focus on the audit task!

It is notable that this very disclosure, coming from the open-ended section of the interview, concurs with the answer provided earlier in the close-ended section of the interview, that the unit conducts operational tasks for the organization. But it is perhaps worth noting that there are other answers from these auditors which do not sit well with those disclosed earlier.

For example, it is revealed during interview that the auditor regularly sends in the audit report to the head of the organization. Another example is concerned with the favorable answer "Yes" given to the following list of daily activities of the audit unit: no obstruction to audit whichever 
departments, records, assets and personnel of the organization; regular access to senior management; free to allocate resources, determine audit frequency, choose subject, ascertain audit scope and the application of audit techniques; and, free to gain assistance from the personnel working in the department where the audit is taking place. Finally, it is notable that the auditor has provided the unfavorable answer "No" to the following daily activity of the audit unit: able to direct the activity of staff from departments other than the audit department.

All in all, cases A, B and C point to the need for and importance of an entity such as the audit committee in public organizations. So, a question may perhaps be raised as to what extent the presence of an audit committee could make a difference in such cases. Unfortunately, from available evidence, it seems that there is not much which could be expected from some of them.

\subsubsection{Audit committee to the rescue?}

It seems that there is a gap between theory and practice in regard to the audit committee in some organizations. This may be deduced from the experiences of two auditors recounted next.

The first auditor:

He or she is attached to an audit unit which is faced with numerous problems and issues including what may be viewed to be the biggest one of all: unsupportive top management. When it concerns the matter of independence in particular, in the close-ended section of the interview, the auditor has already answered "No" to the following statement: free to produce audit reports even when the contents may not be to the liking of certain parties inside the organization. Later, in the open-ended section, he or she mentions that among the main problems faced by the audit staff is that they possess limited independence. This is in the sense that they do not have the total freedom to pinpoint the source of the weaknesses they find.

Next, he or she reveals that the audit committee has not been effective at all. That would be entirely believable since a well-functioning audit committee would not have allowed those things he or she described to happen. The fact that the audit committee has failed to provide support may be detected too from the answers he or she provides in the latter part of the close-ended interview.

First, he or she provides "Agree" as the answer for each of the three statements concerning the interaction between the non-audit personnel and the auditors: that of a lack of understanding over the role of internal auditor as independent examiner; that of a lack of appreciation over the value and importance of internal audit; and, that of a lack of support and cooperation for the audit unit to have it able to conduct its activities successfully. Second, when it concerns the subject of actions to strengthen internal audit in government organizations and related entities, he or she answers "Strongly Agree" for each statement listed including the one over the need for a monitoring body for internal audit and another over the need for relevant legislation to support 
the audit practice. In fact, in the open-ended section, the auditor laments the fact that no such monitoring body exists for internal audit other than the NAD.

The second auditor:

He or she is attached to a thriving audit unit which has been around for over a decade. So many things appear to be quite right for the audit unit - except when it concerns the subject of the audit committee. It seems that every single audit report sent to the audit committee has to go through the CEO. Furthermore, when it concerns performance evaluation and salary increments for the audit staff, the audit committee has got no say whatsoever. It is instead the CEO who oversees these things. All this was revealed during the interview when the auditor talked about the weaknesses experienced by the audit unit. As he or she puts it:

Even though from the hierarchical perspective the unit is reporting direct to the audit committee, the CEO is in charge of the staff performance evaluation and salary increment. Hence, there is doubt over audit independence since the CEO is still having the indirect power over the internal audit unit. ... In addition, the audit report would still need to go through the CEO. Thus, the true independence of internal audit may still be questioned and improved further.

Extrapolating the facts of Cases A, B and C above, there is a need to be suspicious of the very healthy picture as laid out next on various facets of audit independence coming from the close-ended section of interviews. For example, all the auditors say that their organizations have placed the audit units high up in the organizational chart. They also claim that audit findings are frequently communicated to the relevant parties in either written form solely or both written and oral forms.

As for the parties receiving the audit reports, see Table 8. In almost ninety percent or 42 of the organizations, the auditors concerned claim that the organizational heads are the recipients.

Table 8: Audit Report Recipients

\begin{tabular}{lrc}
\hline & Total & $\%$ \\
\hline Head of the organization & 42 & 89.36 \\
Audit committee & 10 & 21.28 \\
Head of finance or accounting department & 17 & 36.17 \\
Other parties & 20 & 42.55 \\
\hline
\end{tabular}

Next, except for auditors from eight organizations, the rest claimed that a written audit report is integrated with management's action plan. This action plan clearly identifies actions to be taken and their deadlines for each of the audit recommendations. When a management action plan fails to be an integrated part of an audit report, an auditee may be required by the organization to give its response by filing action plans with or coming out with other responses to one of the relevant parties in the organization such as the head of the internal audit unit, the head of the organization 
or the audit committee. As it turns out, auditors from four of the eight audit units not providing written audit reports claimed that that is indeed the case - on every single occasion. As for the auditors from the other four audit units, they have mentioned something else which should be rather painful to admit: the giving of feedback would take place on certain occasions only.

As for the question of whether the audit unit monitors the auditee's implementation of the audit recommendations, all but the auditors from five organizations claim that they are required to do so. It is notable that out of five organizations where the auditors are not the monitoring party, two have instead got other parties to play the monitoring role. These parties are the Department of Finance and Accounting and the Audit Committee.

Besides getting feedback from the auditee and the auditor monitoring the implementation of audit recommendations, there are several other facets of independence which the auditors are supposed to experience on a daily basis. For five of these facets the answer "Yes" offered by between 40 and 45 of the audit units' auditors in response to statements requiring a : "Yes", "No", "No Comment" or "Others" response indicates the units are independent. See Table 9a.

Table 9a: Facets of Audit Independence on Daily Basis

\begin{tabular}{|c|c|c|c|c|}
\hline & Yes & $\%$ & $\begin{array}{l}\text { Other } \\
\text { Than } \\
\text { Yes }\end{array}$ & $\%$ \\
\hline $\begin{array}{l}\text { Face no obstruction to audit whichever offices, records, } \\
\text { property and personnel }\end{array}$ & 40 & 85.11 & 7 & 14.89 \\
\hline Have regular access to senior personnel & 41 & 87.23 & 6 & 12.77 \\
\hline $\begin{array}{l}\text { Free to allocate resources, set frequencies, select subjects, } \\
\text { determine scope of work and apply the techniques required } \\
\text { to accomplish audit objectives }\end{array}$ & 43 & 91.49 & 4 & 8.51 \\
\hline $\begin{array}{l}\text { Free to obtain the necessary assistance of personnel in areas } \\
\text { of the organization where audits are performed }\end{array}$ & 45 & 95.74 & 2 & 4.26 \\
\hline $\begin{array}{l}\text { Free to produce audit reports where the contents may not be } \\
\text { to the liking of individuals or groups working or associated } \\
\text { with the organization }\end{array}$ & 41 & 87.23 & 6 & 12.77 \\
\hline
\end{tabular}

In two other facets of independence, the findings are not as favourable. See Table $9 b$.

Table 9b: Audit Independence on Daily Basis

\begin{tabular}{lcccc}
\hline & No & $\begin{array}{c}\text { Other } \\
\text { Than } \\
\text { No }\end{array}$ & $\%$ \\
\hline $\begin{array}{l}\text { Perform operational duties for the organization or its } \\
\text { affiliates such as compiling inventory records, participating } \\
\begin{array}{l}\text { in departmental procurement boards, involvment in } \\
\text { accounting process, etc. }\end{array}\end{array}$ & 38 & 80.85 & 9 & 19.15 \\
\begin{tabular}{l} 
Direct the activities of any organization employee not \\
\hline
\end{tabular} & 30 & 63.83 & 17 & 36.17 \\
\hline
\end{tabular}


employed within the internal audit unit - except to the extent such employees have been appropriately assigned to assist the internal auditors

Regarding the performance of operational duties, auditors from around one fifth or nine of the audit units are unable to say that that does not happen to them. Worse, in regard to the question of directing the activities of non-audit personnel, auditors from more than a third or 17 of the audit units are unable to provide the favorable answer "No". In other words, these units are performing operational duties, and managing non-audit staff on a daily basis. In the former case, it would mean that the auditors are mixing up monitoring functions with line functions. This should not be happening since it could mean that the auditors may one day audit the outcome of their own work. If that were to take place, the auditors would inevitably find it difficult to report the truth. As for the latter, they are not supposed to do so since these people (who are not among those who have been appropriately assigned by their bosses to assist the internal auditors) could very well be the party whose conduct the auditors may one day evaluate.

Finally, when the auditors were asked whether they had encountered threats for performing their jobs, only auditors from seven organizations acknowledged that such things had happened to them. It may be interesting to note that the threats to these seven auditors came in a variety of forms ranging from mild ones, such as getting phone calls from strangers and receiving poison pen letters, to harsh ones such as getting demotion and being transfer to another location!

\subsection{Interaction between Auditors and Other Parties in the Organization}

It is important that a good relationship exists between the auditors and other parties in the organization. Without such rapport, the auditors might as well not be around. And if they are still around, their job experience usually becomes quite a painful one. The following three cases detail the goings-on when the auditors are facing interaction problems with both top management and the rest of the personnel in their organizations!

Case A:

The audit unit was set up relatively recently. From various parts of both close- and open-ended sections of the interview, the auditor provided answers that show that this very small audit staff complement is facing quite an appalling job environment. When it concerns auditor and top management interaction, for example, in the close-ended section of the interview the auditor responded "Strongly Disagree" to the statements that relevant parties inside the organization have regularly implemented the audit suggestions and that management provides sufficient feedback to the audit unit after having been informed of audit findings and suggestions. As for the two (out of three) statements related to interaction with non-audit personnel inside the organization, the answer is also "Strongly Agree". That is, there is a lack of understanding regarding the role of internal auditor as independent examiner in the organization, and that there is also a lack of appreciation of the value and importance of the audit unit in the organization. 
Later, in the open-ended section of the interview, the auditor identified the main problem faced by the audit unit as being the failure of the rest of the people in the organization to understand the role of the auditor clearly and to give value to the audit function. In fact, their colleagues view the auditor as a nuisance! This is perhaps inevitable since top management has failed to make it clear to the rest of the organization the value of the function played by the audit unit. Even though top management once attempted to explain the significance of all the various departments within the organization to all its employees, the internal audit department was (possibly deliberately) not mentioned at all. This has led the auditor to feel disheartened.

Case B:

The audit unit has been around for two decades. It is probably one of the saddest audit units around, facing numerous issues and problems. During the interview, it was disclosed that one of the main problems faced by the unit concerned top management giving audit suggestions the cold shoulder. In fact, cases exist where top management has rejected outright the disclosures made in audit reports. Once, an audit head of this unit was even demoted for issuing an "aggressive" audit report!

All this information is consistent with the answers provided in the close-ended section of the interview related to the subject of audit - top management interaction. To be more exact, the auditor has chosen "Disagree" as the answer for each of the three statements related to top management: that of recognizing the achievement of audit unit; that of implementing audit suggestions regularly; and that of providing sufficient feedback to the audit unit upon getting the audit findings and suggestions. In fact, in regard to the third statement, the following comment was attached:

Fail to give serious attention to internal audit reports.

Perhaps all this is to be expected when in the first place, there are issues of disagreement between the current audit head and top management. It appears that somebody else who is supposed to be in the position of audit head has been moved to an accountant post to give way to the current audit head who is a mere administrator and who has no knowledge about internal auditing. This person is expected to remain as audit head until his or her retirement several years from now.

With top management causing these situations that beset the audit unit, it is perhaps not surprising to find that the auditors have a strained relationship with the rest of the personnel in the organization. That is, the rest of the organization takes their antagonistic cue from the top. The less-than-cozy relationship between audit and non-audit personnel may be deciphered from the answer "Agree" given to each of the three statements which concern the interaction between the two parties: that there is a lack of understanding regarding the auditor's role as independent examiner; that there is a lack of appreciation for the value and importance of the audit unit; and, that there is a lack of support and cooperation for the audit unit in ensuring the success of its 
audit activities. In fact, in relation to the third and last statement, the added comment is that there is difficulty in getting the needed documents on time from the non-audit personnel.

\section{Case C:}

The audit unit has been around since the early 1980s, but to this day it still has only two members of staff, when the work load now requires eight times more! But, not only is the staff number absolutely minimal, there is also no training and development program whatsoever for the auditors. Minimal staff numbers and no training programs are unfortunately not the only issues faced by the auditors in their working environment. In fact, the litany of issues and problems they face is truly mind-boggling. In short, for this particular audit unit, misery might very well be its middle name!

From the close-ended section of the interview, it was already apparent that a thorny relationship exists between audit and non-audit personnel. Specifically, the auditor has responded "Agree" to each of the three statements listed regarding auditor/non-auditor interactions: that there is a lack of understanding over the role of internal auditor as independent examiner; that there is a lack of appreciation over the value and importance of internal audit; and, that there is a lack of support and cooperation for the audit unit to have it able to conduct its activities successfully. Surprisingly, the auditor failed to refer even once during the open-ended section of the interview to the difficult relationship between audit and non-audit personnel. On the other hand, when it concerns the difficult relationship the unit has had with the very top of the organization, he or she is quite forthcoming.

Actually, early on in the close-ended section of the interview, the auditor provided an inkling that the audit unit has not had an easy relationship with the organizational head. That is, in regard to the question of whether changes to the role and responsibilities of the audit unit may be expected in the years to come, the auditor responded "No", and immediately adding:

The situation faced by the internal auditor who is not independent from the chief executive has brought difficulties in the conduct of audit tasks.

And then, responding to the question whether the audit head has regular meeting with the top, the answer provided was also "No". Later, in the open-ended section of the interview, the auditor, who has been working in the organization for close to 30 years, the last fifteen or so years as the audit head, detailed the painful realities the audit staff have gone through over the years.

Early on he or she mentioned the limited role played by the unit and the lack of support for the unit coming from the top of the organization. He or she revealed that two audit staff in fact left the organization some years back due to their issuance of audit reports which were not to the liking of the top management. Next, he or she mentioned that it would be better for the 
organization if the auditors were to come from the NAD instead of having their appointment decided by the organization itself.

It appears that the fact that the audit head is at a salary grade much lower than the organizational head and other members of management has led these parties to ignore the existence of the unit. This may perhaps be seen by the fact that every single audit report issued has failed to generate the recommended action on the part of the auditee. That the audit unit is being ignored may be seen too in the fact that the audit head has been called up to attend management meetings only once throughout the time the unit has been in operation! But, according to the auditor, this may have also been brought about by the fact that management is too afraid to face up to the auditors! Final proof that the audit unit has been ignored is seen by the fact that to this day neither one of the audit staff has been honored with an excellence award by the organization. This is in comparison to the rest of the staff of the organization who have all received this award, including the one member who was earlier caught by the audit unit for perpetrating fraud!

It seems the working environment faced by the auditors has got even worse with the recent appointment of a new organizational head. With the previous organizational head, who was a personal friend of the audit head, he or she would still be asking for the views of the audit head from time to time - not as an auditor but rather as a personal friend. With the present head of the organization, this does not happen at all. In fact, as reported by the auditor, the head now tries to avoid meeting up with the audit head. It seems that the view held by the head of the organization is this: he or she and the rest of the organization would still be able to do their work successfully without the auditors being involved!

In reading all this, it may be worth noting that the response provided by the auditor to some questions in the close-ended section of the interview under the heading auditor/top management interaction failed to agree with those statements quoted above. Specifically, the auditor chose "Agree" as the answer to two out of the three statements relating to top management. The statements are: the recommendations by the internal audit unit are usually implemented by the relevant parties in the organization; and the internal audit unit receives adequate feedback from management on its audit findings and recommendations. It is however notable that the same auditor provided the answer "Uncertain" for the statement on top management recognizing the achievement of the audit unit.

Cases A, B and C provide a negative picture of the relationship the auditors in the units have with both top management and other staff members in the organizations. Fortunately, these cases do not appear to be representative of what is taking place for a majority of the audit units. This is especially true when it concerns auditor/top management interaction in comparison to that of auditor/non-auditor interaction.

4.6.1 Audit / top management interactions

As may be seen in Table 10a, auditors and top management appear to have good relationships in a majority of the organizations. To be more exact, auditors from close to 90 percent or 42 of the 


\section{Macrothink}

organizations have responded either "Strongly Agree" or "Agree" to the statement that top management recognizes the accomplishments of their audit units. And, auditors from around 85 percent of the audit units concur with the statement that management implements the audit recommendations regularly and with that of management providing feedback to the auditor upon receiving the audit findings and recommendations.

Also, it may be worth pointing out that in responding to other close-ended questions, close to 90 percent or 42 of the audit units report that they conduct regular meetings with the top management in their organizations. The frequency of such meetings is presented in Table 11.

Table 11: Frequency of Meeting with Top Management per year

\begin{tabular}{lcc}
\hline & Total & $\%$ \\
\hline Fewer than 3 & 1 & 2.38 \\
Between 3 to 7 & 22 & 52.38 \\
Over 7 times & 19 & 45.24 \\
\hline Total & 42 & 100.00 \\
\hline
\end{tabular}

4.6.2 Audit / other non-audit personnel interaction

While good relationships appear to be the case between auditors and top management in a majority of the organizations, the same cannot be said between auditors and the rest of the organization's employees in a good percentage of the organizations. As shown in Table 10b, auditors from close to two fifths or 18 of the audit units have answered either "Strongly Agree" or "Agree" in response to the statement that there is a lack of understanding of the audit role within their organization. As for the statement regarding the lack of appreciation for the value of audit and that of the lack of support and cooperation for auditors coming from non-audit staff, auditors from over one fifth or 12 audit units have answered either "Strongly Agree" or "Agree". 
Table 10a: Audit - Top Management Interaction

\begin{tabular}{|c|c|c|c|c|c|c|c|c|c|c|}
\hline & \multicolumn{2}{|c|}{$\begin{array}{l}\text { Strongly } \\
\text { Agree }\end{array}$} & \multicolumn{2}{|c|}{ Agree } & \multicolumn{2}{|c|}{ Not Sure } & \multicolumn{2}{|c|}{ Disagree } & \multicolumn{2}{|c|}{$\begin{array}{l}\text { Strongly } \\
\text { Disagree }\end{array}$} \\
\hline & Total & $\%$ & Total & $\%$ & Total & $\%$ & Total & $\%$ & Total & $\%$ \\
\hline $\begin{array}{l}\text { Top management recognizes the accomplishments of } \\
\text { internal audit unit }\end{array}$ & 24 & 51.06 & 18 & 38.30 & 4 & 8.51 & 1 & 2.13 & 0 & 0.00 \\
\hline $\begin{array}{l}\text { The recommendations by the internal audit unit are } \\
\text { usually implemented by the relevant parties in the } \\
\text { organization. }\end{array}$ & 17 & 36.17 & 23 & 48.94 & 2 & 4.26 & 4 & 8.51 & 1 & 2.13 \\
\hline $\begin{array}{l}\text { The internal audit unit receives adequate feedback } \\
\text { from management on its audit findings and } \\
\text { recommendations. }\end{array}$ & 18 & 38.30 & 23 & 48.94 & 1 & 2.13 & 4 & 8.51 & 1 & 2.13 \\
\hline
\end{tabular}

Table 10b: Audit - Non-Audit Personnel Interaction

\begin{tabular}{|c|c|c|c|c|c|c|c|c|c|c|}
\hline & \multicolumn{2}{|c|}{$\begin{array}{l}\text { Strongly } \\
\text { Agree }\end{array}$} & \multicolumn{2}{|c|}{ Agree } & \multicolumn{2}{|c|}{ Not Sure } & \multicolumn{2}{|c|}{ Disagree } & \multicolumn{2}{|c|}{$\begin{array}{l}\text { Strongly } \\
\text { Disagree }\end{array}$} \\
\hline & Total & $\%$ & Total & $\%$ & Total & $\%$ & Total & $\%$ & Total & $\%$ \\
\hline $\begin{array}{l}\text { There is a lack of understanding of the role of } \\
\text { internal audit as an independent appraisal function } \\
\text { within the organization. }\end{array}$ & 4 & 8.51 & 14 & 29.79 & 4 & 8.51 & 23 & 48.94 & 2 & 4.26 \\
\hline $\begin{array}{l}\text { There is a lack of appreciation of the value and } \\
\text { importance of the intermal audit unit in the } \\
\text { organization. }\end{array}$ & 2 & 4.26 & 10 & 21.28 & 7 & 14.89 & 20 & 42.55 & 8 & 17.02 \\
\hline $\begin{array}{l}\text { There is little support and minimal cooperation } \\
\text { coming from others in the organization for the } \\
\text { intermal audit unit to be able to conduct its activities } \\
\text { successfully. }\end{array}$ & 2 & 4.26 & 10 & 21.28 & 7 & 14.89 & 20 & 42.55 & 8 & 17.02 \\
\hline
\end{tabular}

\subsection{Discussion and Conclusions}

Results relating to the primary concern of this research project show that the internal audit function in numerous statutory bodies and government-linked companies studied has a number of grave deficiencies. To be more exact, there is a significant percentage of these organizations where the internal audit units or departments are not able to operate effectively as a result of an acute shortage of staff and the employment of staff lacking in appropriate skills. In addition, in a majority of these organizations, the internal auditors are still performing financial management audits. Last but certainly not the least, in regard to the relationship between audit and non audit personnel, there is still some room for improvement in a good number of the organizations.

Having said all that, in most organizations it appears that the level of independence of internal auditors is high and good rapport exists between auditors and the top management. But what good would these positive features do when the very foundation of internal audit in terms of an appropriate staff complement, complete with up-to-date competencies is nowhere to be found?

All in all, these findings on internal audit in the statutory bodies and government-linked companies echo those found earlier in the internal audit study conducted on the state and local governments (Azham et al 2007a) and that for the federal government ministries, departments and agencies (Azham et al 2007b). As stated by Azham et al (2007a:47) in the case of the state and local governmental bodies (SLoGBs): 


\section{Ml Macrothink}

Within the 35 SLoGBs that do have internal audit operations the two greatest inhibitors to efficient and effective operations are the lack of audit personnel and the audit personnel's lack of appropriate skills and competency for the tasks required of them. Less immediately obvious factors identified in this research include the rather difficult interaction between audit and non-audit personnel and between audit personnel and top management. It has become obvious that so many internal audit operations in these SLoGBs still operate at a very simple, compliance-checking level, while for a significant minority independence of the auditors is a goal not yet in sight.

As for the goings-on in the federal ministries, departments and agencies, Azham et al (2009:33) have this to say:

In Malaysia, the internal audit function in many federal organizations studied has a number of serious shortcomings. The two areas that need most urgent attention are the staff numbers in the audit units or departments, and the competency of the audit staff. There is a high percentage of these organizations where the internal audit units or departments are not able to operate effectively as a result of the acute shortage of staff and of staff lacking in appropriate audit skills. Furthermore, while the world trend, and including some members of Malaysia's listed companies, is that internal auditors have moved to risk-based auditing, in a majority of Malaysia's federal organizations, the internal auditors are still performing financial management audits.

Indeed, for so many problematic organizations at the federal, state and local levels, what justification can there be for having an understaffed audit unit unable to provide appropriate audit coverage, when the organizational budget reaches hundreds of million of ringgit per year and the organization maintains a workforce of tens of thousands? Also, what justification can there be for expecting these few auditors to conduct any meaningful audit since they are largely under-trained and without appropriate work experience, which renders them incompetent to perform the job in the first place?

The fact that there is no justification whatsoever, as stated in Azham et al (2009), does however raise the perverse notion that this might be the exact intention of "vested interests" from both inside and outside the organizations, so that by ensuring that these government organizations have insufficient and incompetent internal auditors they might better succeed at their clandestine and nefarious endeavours!

Some may believe that this is mere conjecture. Nonetheless, there exists evidence that says otherwise. In a recent survey conducted by the independent Merdeka Centre and commissioned by the Centre for Independent Journalism, the focus was on corruption and the media's role in the country (Merdeka Center 2009). The survey, which is financially supported by the Friedrich Naumann Foundation (FNF), comprises two parts: one quantitative and the other qualitative. For the former, over 1,200 people from all over Malaysia, aged 20 and above, were interviewed 
via telephone from 16 September to 12 October 2009. As for the latter, two focus groups were conducted among twenty participants living in Klang Valley.

Among the notable findings is that corruption and abuse of power were number one on the list of problems that respondents think are besetting the country. Also, 81 percent believe that corruption is serious in Malaysia. In addition, 74 percent indicated that they are dissatisfied with the way the federal government is handling the issue. In fact, less than $50 \%$ feel that institutions tasked to fight corruption are effective. Finally, from among those saying the country is moving in the wrong direction, corruption is considered to be a principal factor defining this perception.

In recent time, several parties from both inside and outside the country have given exposure to the wide extent of corruption in the country. Three are mentioned here while the rest are mentioned in Azham et al (2011). The first is Lim Guan Eng, the current chief minister of Penang, who claimed in Parliament that in 2004 the international investments and finances services giant Morgan Stanley had estimated that as much as US\$100 billion (then RM380 billion) had been squandered through corruption over the past two decades (Malaysiakini 2008). (Note: Apparently, Lim had earlier found this information in an article dated March 152004 in Time magazine whose writer, Simon Elegant, mentioned the following coming from Daniel Lian who was a Southeast Asia economist at Morgan Stanley in Singapore: "Lian figures that the country may have lost as much as $\$ 100$ billion since the early 1980 s to corruption.")

The second party talking about corruption is Barry Wain who is the author of a book on the former Prime Minister Mahathir Mohamad (Berthelsen 2009). In "Malaysian Maverick: Mahathir Mohamad in Turbulent Times" published by Palgrave Macmillan, Wain, who was granted access to the former premier for a series of exhaustive interviews, disclosed that Mahathir may well have wasted or burned up as much as RM100 billion (US $\$ 40$ billion at earlier exchange rates when the projects were active) on grandiose projects and the corruption that the projects engendered as he sought to turn Malaysia into an industrialised state. Wain, the former editor of Asian Wall Street Journal, who is currently a writer in residence at the Institute of South-east Asian Studies in Singapore, has this to say early on in his book (Berthelsen 2009):

Dr Mahathir's decision to direct the ruling party into business in a major way while the government practiced affirmative action, changed the nature of the party and accelerated the spread of corruption. One manifestation was the eruption of successive financial scandals, massive by any standards, which nevertheless left Dr Mahathir unfazed and unapologetic.

The third and final party disclosing the widespread extent of corruption in the country is none other than Tengku Razaleigh Hamzah the Finance Minister during the 1980s. He, who has been a parliamentarian since the late 1960s, made a number of revealing remarks in a speech he delivered in late 2009 at the The 1st Young Corporate Malaysians Summit (Razaleigh 2009). Early on he mentioned the debilitated state of the nation's economy, and followed up with a horrendous outlook on its natural, social and political environments. As he puts it: 
Our cultural diversity is in danger of coming apart in bigotry, our rainforests are being logged out and planted over, our social and political institutions are decaying.

Right after that, he has this to say:

I have spoken at length on different occasions about the causes and consequences of institutional decline. The decline in our society and indeed in our natural environment, originates in a decline in our basic institutions. The link between these is corruption. The destruction of our ecosystem for example, is made possible by corrupt officials and business-people. The uncontrolled influx of unskilled labour is a direct result of corruption.

Soon after mentioning this, in the latter half of his speech he came out with a more distressing disclosure on the manner in which the nation's oil wealth has been squandered over the years. Under a section of the speech titled "Blessing and Curse", this is how he puts it:

Instead of being our ace up the sleeve, however, our oil wealth became in effect a swag of money used to fund the government's operational expenditure, to bail out failing companies, buy arms, build grandiose cities amidst cleared palm oil estates. Instead of helping eradicate poverty in the poorest states, our oil wealth came to be channeled into the overseas bank accounts of our political and politically-linked class. Instead of being the patrimony of all Malaysians, and for our children, it is used as a giant slush fund that has propped up authoritarian rule, eroded constitutional democracy and corrupted our entire political and business elite. Our oil receipts, instead of being applied in the manner we planned upon the formation of Petronas, that is, according to its original developmental purpose, became a fund for the whims and fancy of whoever ran the country, without any accountability.

At the end of his exposé on the squandering of oil wealth, he made the following devastating remark:

Malaysia is now an "oil cursed" country. We managed to arrive at this despite not having a lot of oil. When I started Petronas in 1974, I did not realise I would see the day when I would wish we had not uncovered this bounty.

Finally, within the last few paragraphs of his speech, he has the following advice for the audience:

You have kindly invited me to address a seminar on strategies for reinventing and liberalising Malaysia's economy. But the story of our squandered oil wealth reminds us that it was not for want of resources or strategies that we floundered. Our failure has been political and moral. We have allowed greed and resentment to drive our politics and looked the other way or even gone along while public assets have been stolen in broad daylight. I encourage you to take up the cause of national development with the ingenuity that earlier generations of Malaysians brought to this task, but the beginning of our journey must be a 


\section{Macrothink}

return to the basics of public life: the rule of law, honesty, truth-telling and the keeping of promises. (Emphasis added.)

On the whole, it may safely be concluded that the case of (mal)functioning internal audit in the public sector of Malaysia shall remain a never-ending story as long as the decadent socio-politico environment stays intact. Such a dysfunctional internal audit function fits in like hands to gloves with that corrupt environment. Stated another way, a well functioning internal audit function - if it were to exist - would be incongruent with such an environment.

With the assumption that this debilitating setting is likely to persist for years to come, there is much food for thought for concerned parties inside the nation's public sector in the quote below from Diamond (2002:8), and justifying the idea of putting aside the idea of achieving global standards of internal audit performance in public organizations. As Diamond (2002:8) of the International Monetary Fund (IMF) has put it:

... the recognition that IA has evolved in a particular institutional, legal, and political environment, which varies markedly in different groups of countries, raises an important question of the wider applicability and practicality of these standards, especially for the government sector. Even within OECD countries, there is a wide disparity in the role assigned to the IA, as well as the way it is organized, which results in diverse IA practices. Such diversity is also reflected in other parts of the world where the IMF has offered advice in strengthening and reforming the IA.

Specifically, in his IMF Working Paper, Diamond argues that the international internal audit standards issued by the International Organization of Supreme Audit Institutions (INTOSAI) as well as the Institute of Internal Auditors that private and public sectors throughout the world should meet, may not be appropriate for many countries that are still developing or are in transition. He mentions that these countries would face severe problems of meeting such standards because of the presence of different audit traditions and different institutional capacities compared to those few advanced countries where these international standards come from.

So, is the public sector of Malaysia prepared to implement Diamond's proposal? That would, in a nutshell, signal to all and sundry that internal audit in government organizations is not of world standard - on paper and also in practice - and that the country is not quite what it portrays itself to be audit-wise and hence governance-wise. Or, does it opt to continue with the status quo with the certainty that the internal audit in these organizations shall be one of a quagmire of a never-ending story? 


\section{Macrothink}

\section{References}

Auditor-General (Australia). (1990). Survey of Internal Audit in the Commonwealth Public Sector (Australian National Audit Office, Canberra).

Azham, M.A., Aidi, A., Azharudin, A., Mohamad-Zulkurnai, G., Gloeck, J.D. \& Lee, T.H. (2009). Internal Audit in the Federal Organizations: Is there Light at the End of the Long Dark Tunnel? Southern African Journal of Accountability and Auditing Research, 9: 23-38.

Azham, M.A., Gloeck, J.D., Azharudin, A., Aidi, A. \& Mohd.-Hadafi, S. (2007a). Internal Audit in the State and Local Governments of Malaysia. Southern African Journal of Accountability and Auditing Research, 7: 25-57.

Azham, M.A. Mohd.-Hadafi, S., Sazali, S. \& Gloeck, J.D. (2011). Internal Audit in Statutory Bodies and Government-Linked Companies of Malaysia: Dream of Dreams? Southern African Journal of Accountability and Auditing Research, Forthcoming.

Azham, M.A., Siti-Zabedah, S., Mohd.-Hadafi, S., Mohamad-Zulkurnai, G., Mohd.-Hadzrami, H-R., Mohd-Syahrir, R., Azharudin, A. \& Aidi, A. (2007b). "Internal Audit in the Federal Government Ministries, Departments and Agencies of Malaysia" in the proceedings for the Universiti Utara Malaysia organized Accounting Studies International Conference 2007 (ASIC '07), 29-31 October, Kuala Lumpur.

Berthelsen, J. (2009). Malaysiakini. Mahathir's Secret Deal with US Military. 5 December.

Brierley, J.A., El-Nafabi, H.M. \& Gwilliam, D.R. (2001). The Problems of Establishing Internal Audit in the Sudanese Public Sector. International Journal of Auditing. 5: 73-87.

Buttery, R. (1985). Widening Role of Audit. Public Finance and Accountancy. February: 41.

Coombs, H. \& Jenkins, E. (1994). Public Sector Financial Management. $2^{\text {nd }}$ ed. (Thomson Learning, London).

Diamond, J. (2002). 'The Role of Internal Audit in Government Financial Management: An International Perspective', IMF Working Paper 02/94 (International Monetary Fund, Washington D.C.).

Dowsett, P. \& Morris, T. (1981). Implementing CIPFA's Internal Audit Statements. Public Finance and Accountancy. February: 41.

Ernst \& Young. Malaysian Institute of Corporate Governance (MICG) and Institute of Internal Auditors Malaysia (IIAM). (2000). Profile of Internal Audit in Malaysia: Preliminary Survey Results (Ernst \& Young, Kuala Lumpur). 


\section{Macrothink}

Journal of Public Administration and Governance

ISSN 2161-7104

2011, Vol. 1, No. 2

Institute of Internal Auditors (IIA). (1979). Standards for the Professional Practice of Internal Auditing (IIA, Altamonte Springs).

Institute of Internal Auditors (IIA). (2003). International Standards for the Professional Practice of Internal Auditing. [Online] http://www.theia.org/ecm/guidance.cfm?doc_id=1499. Accessed: 30 December 2003.

Jones, R. \& Pendlebury, M. (2000). Public Sector Accounting. $5^{\text {th }}$ ed. (Financial Times/Prentice Hall, London).

Kvale, S. (1996). InterViews: An Introduction to Qualitative Research Interviewing. (Sage, London).

Light, P. (1993). Monitoring Government: Inspectors General and the Search for Accountability (Brookings, Washington, D.C.).

Malaysian Institute of Accountants (MIA). (1989). An Overview of Internal Audit in Malaysia: Report No. 1 (Malaysian Institute of Accountants, Kuala Lumpur).

Malaysian Institute of Accountants (MIA). (1991). An Overview of Internal Audit in Malaysia: Report No. 2 (Malaysian Institute of Accountants, Kuala Lumpur).

Malaysiakini. (2008). RM380b Lost Through Graft Over 20 Years, Parliament Told. 24 June.

Mathews, C.M.H., Cooper B.J. \& Leung, P. (1995). A Profile of Internal Audit in Malaysia - 1994 (Institute of Internal Auditors in Malaysia, Kuala Lumpur).

Merdeka Center. (2009). Malaysian Public Perspectives on the Role of the Media in Reporting Corruption 2009. [Online] http://www.merdeka.org/v2/download/Media\%20role\%20in\%20reporting\%20corruption\%20(16th\%2 ONov).pdf. Accessed 10 December 2009.

Nair, J. (2008). Progress with the Implementation of the PFMA. Auditing SA. Summer 2007/8:7-55.

Newcomer, K.E. (1994). Opportunities and Incentives for Improving Program Quality: Auditing and Evaluating. Public Administration Review. 54(2): 147-54.

(1998). The Changing Nature of Accountability: The Role of the Inspector General in Federal Agencies. Public Administration Review. 58(2): 129-36.

New Straits Times. (2004). Financial Management Committee for Every Ministry. 18 December.

Office of the Auditor General (Canada). (1993). Internal Audit. 
. (1996). Internal Audit in Departments and Agencies.
Razaleigh,
$\mathrm{H}$.
(2009).
A
Blessing
Become
a Curse.

http://razaleigh.com/2009/12/12/a-blessing-become-a-curse/ Accessed: 20 December 2009.

Ridley, J. \& Chambers, A. (1998). Leading Edge Internal Auditing (Prentice Hall, London).

Schwartz, R. \& Sulitzeanu-Kenan, R. (2002). The Politics of Accountability: Institutionalising Internal Auditing in Israel. Financial Accountability \& Management. 18(3): 211-31.

\section{Appendix 1. List of Federal Government Organizations}

\section{STATUTORY BODIES}

University of Malaya (Universiti Malaya - UM)

Sultan Idris Education University (Universiti Pendidikan

Sultan Idris - UPSI)

Putra University, Malaysia (Universiti Putra Malaysia -

UPM)

Islamic Science University of Malaysia (Universiti Sains Islam Malaysia - USIM)

University of Science, Malaysia (Universiti Sains Malaysia - USM)

Northern University of Malaysia (Universiti Utara Malaysia - UUM)

National Higher Education Fund Corporation (Perbadanan Tabung Pendidikan Tinggi Nasional PTPTN)

Intellectual Property Corporation of Malaysia (Perbadanan Harta Intelek Malaysia)

Malaysian Handicraft Development Corporation (Perbadanan Kemajuan Kraftangan Malaysia)
Kedah Regional Development Authority (Lembaga

Kemajuan Wilayah Kedah - KEDA)

Muda Agriculture Development Authority (Lembaga Kemajuan Pertanian - MADA)

Malaysian Rubber Board (Lembaga Getah Malaysia)

Malaysian Fisheries Development Authority (Lembaga Kemajuan Ikan Malaysia - LKIM)

Malaysian Highway Authority (Lembaga Lebuhraya Malaysia - LLM)

Malaysian Palm Oil Board (Lembaga Minyak Sawit Malaysia - MPOB)

National Population and Family Development Board (Lembaga Penduduk dan Pembangunan Keluarga Negara - LPPKN)

Construction Industry Development Board (Lembaga Pembangunan Industri Pembinaan Malaysia - CIDB)

Federal Agriculture Marketing Authority (Lembaga Pemasaran Pertanian Persekutuan - FAMA) 
Council of Trust for the Bumiputera (Majlis Amanah

Rakyat - MARA)

Malaysian Examinations Council (Majlis Peperiksaan

Malaysia - MPM)

Companies Commision of Malaysia (Suruhanjaya

Syarikat Malaysia - SSM)

Social Security Organisation (Pertubuhan Keselamatan

Sosial - PERKESO)

Agriculture Bank of Malaysia (Bank Pertanian

Malaysia) (from April 82008 onward: Agrobank)
Inland Revenue Board (Lembaga Hasil Dalam Negeri LHDN)

Penang Regional Development Authority (Lembaga Kemajuan Wilayah Pulau Pinang - PERDA)

Forest Research Institute of Malaysia (Institut Penyelidikan Perhutanan Malaysia - FRIM)

Malaysia Agricultural Research \& Development

Institute (Institut Penyelidikan dan Kemajuran Pertanian Malaysia - MARDI)

\section{GOVERNMENT-LINKED COMPANIES}

International Islamic University (Universiti Islam

Antarabangsa - UIA)

Amanah Raya Berhad (ARB)

Bursa Malaysia Berhad

Federal Land Development Authority (Lembaga

Kemajuan Tanah Persekutuan - FELDA)

Federal Land Consolidation and Rehabilitation

Authority (Lembaga Penyatuan dan Pemulihan Tanah

Persekutuan - FELCRA)

Indah Water Konsortium Sdn Bhd

Malayan Railways Limited (Keretapi Tanah Melayu

Berhad - KTMB)

Kolej Poly-Tech Mara (KPTM)

Malaysia Airports Holdings Bhd (MAHB)
Padiberas Nasional Berhad (BERNAS)

Penang Port Sdn Bhd (PPSB)

Pengurusan Danaharta Nasional Bhd

Permodalan Nasional Berhad (PNB)

Malaysian Rubber Development Corporation Bhd (MARDEC)

Percetakan Nasional Malaysia Berhad (PNMB)

Syarikat Perumahan Negara Bhd (SPNB)

Telekom Malaysia Berhad (TM)

UDA Holdings Berhad 
Malaysian Timber Industry Board (Lembaga

Perindustrian Kayu Malaysia - MTIB)

SME Bank 


\section{Al Macrothink}

\section{Appendix 2. List of Positions Held by Interview Participants}

\begin{tabular}{lc}
\hline \multicolumn{1}{c}{ POSITION } & TOTAL \\
\hline Accountant & 1 \\
Audit Executive & 2 \\
Auditor & 3 \\
Internal Auditor & 2 \\
Senior Auditor & 1 \\
Head of Internal Audit & 7 \\
Group Head of Internal Audit & 3 \\
Group Head of Internal Audit and Risk Management & 1 \\
Head of Audit & 1 \\
Head of Internal Auditor & 1 \\
Head of Internal Audit Unit & 6 \\
Director of Internal Audit & 1 \\
Director of Internal Audit Section & 2 \\
Director of Internal Audit Department & 1 \\
Manager & 1 \\
Manager of Internal Auditing & 1 \\
General Manager & 1 \\
General Manager of Audit & 1 \\
General Manager of Internal Auditing and Compliance & 1 \\
Manager of Internal Auditing Department & 1 \\
Senior Manager & 1 \\
Senior Manager of Audit & 1 \\
Senior Manager of Internal Auditing & 1 \\
Senior Manager of Internal Audit Department & 1 \\
Manager of Internal Audit Unit & 1 \\
Audit Assistant & 1 \\
Assistant Manager & 1 \\
Deputy Manager & 1 \\
\hline TOTAL & 1 \\
\hline & 1 \\
\hline
\end{tabular}

